\section{Escherichia coli as an indicator of bacteriological quality of water: an overview}

\author{
Stephen T. Odonkor, ${ }^{1}$ Joseph K. Ampofo² \\ ${ }^{1}$ Radiological and Medical Sciences \\ Research Institute, Ghana Atomic Energy \\ Commission, Accra; ${ }^{2}$ Environmental \\ Biology and Health Division, Water \\ Research Institute, Council for Scientific \\ and Industrial Research (CSIR), Accra, \\ Ghana
}

\section{Abstract}

Monitoring the microbiological quality of drinking water relies largely on examination of indicator bacteria such as coliforms, Escherichia coli, and Pseudomonas aeruginosa. $E$. coli is a member of the faecal coliform group and is a more specific indicator of faecal pollution than other faecal coliforms. Two key factors have led to the trend toward the use of $E$. coli as the preferred indicator for the detection of faecal contamination, not only in drinking water, but also in other matrices as well: first, the finding that some faecal coliforms were non faecal in origin, and second, the development of improved testing methods for $E$. coli. The faecal coliform definition has also been revised to coincide better with the genetic make-up of its members and now includes newly identified environmental species. As a result, faecal coliforms are increasingly being referred to as thermotolerant coliforms. This, combined with improved detection methods for $E$. coli, has started a trend toward the use of $E$. coli in place of thermotolerant coliforms as a more reliable indicator of faecal pollution in drinking water. At present, $E$. coli appears to provide the best bacterial indication of faecal contamination in drinking water. This is based on the prevalence of thermotolerant (faecal) coliforms in temperate environments as compared to the rare incidence of $E$. coli, the prevalence of $E$. coli in human and animal faeces as compared to other thermotolerant coliforms, and the availability of affordable, fast, sensitive, specific and easier to perform detection methods for $E$. coli.

\section{Introduction}

Water is a natural resource and is essential to sustain life. Accessibility and availability of fresh clean water does not only play a crucial role in economic development and social welfare, but also it is an essential element in health, food production and poverty reduction. ${ }^{1}$ However, safe drinking water remains inaccessible for about 1.1 billion people in the world and the hourly toll from biological contamination of drinking water is 400 deaths of children below the age five. ${ }^{2}$

Water helps maintain the moisture of internal organs of the body; 3 maintains normal volume and consistency of fluids such as blood and lymph; ${ }^{4}$ regulates body temperature; removes poisons or toxins from the body through urine, sweat and breathing; ${ }^{5}$ and is essential for regulating the normal structure and functions of the skin. ${ }^{6}$ The body loses about four liters of water every day. ${ }^{3}$ It is therefore necessary to replenish this volume by drinking at least the equivalent amount of quality water every day.In developing countries with deteriorating environments, the demand for clean drinking water supply is growing rapidly in recent times. ${ }^{7}$ In Ghana, the supply of piped water is inadequate in most communities. This inadequacy is both in quantity and quality of public water supply. Only $40 \%$ of the total urban population has direct access to piped water. On the whole, only about 10.3 million people (approx. 51\% of the population) are reported to have improved water supplies. ${ }^{8}$ Those who do not have access to safe water, as well as those who have access but cannot afford, rely on other sources of water with questionable quality. ${ }^{9}$

The microbiological quality of drinking water is a concern to consumers, water suppliers, regulators and public health authority alike. The potential of drinking water to transport microbial pathogens to great number of people, causing subsequent illness is well documented in countries at all levels of economic development. ${ }^{10,11}$ It is stated that, most sporadic cases of waterborne intestinal illness will not be detected or if detected, may not be recognized as water related. ${ }^{12}$ Several researchers have attempted to estimate the total burden of waterborne diseases world-wide. Waterborne disease might account for one-third of the intestinal infections world-wide, ${ }^{13}$ while it is estimated that water, sanitation and hygiene were responsible for $40 \%$ of all deaths and $5.7 \%$ of the total disease burden occurring worldwide. ${ }^{14}$ Human, livestock and wild animals are all sources of faecal contamination; in general, human faecal waste gives rise to the highest risk of waterborne disease. ${ }^{15} \mathrm{~A}$ wide spectrum of pathogenic agents can be found in water and monitoring for their presence on a routine basis is impractical. Traditionally, microbial safety of drinking water has been confirmed by monitoring for absence of microorganisms of faeces origin. ${ }^{16}$

The importance of quality changes in distribution is based upon evidence concerning the frequency and extends of known quality
Correspondence: Stephen T. Odonkor, Radiological and Medical Sciences Research Institute (RAMSRI), Ghana Atomic Energy Commission, P.O. Box LG 80, Legon-Accra, Ghana.

Tel. $+23320986221,+233234709702$

Fax: +233302400807 .

E-mail: stodonkor@yahoo.co.uk

Key words: Escherichia coli, water quality, indicator, trends.

Contributions: conception and design were done by STO and JKA; STO drafted the manuscript. All authors edited the manuscript.

Conflict of interests: the authors declare no potential conflict of interests.

Received for publication: 31 August 2011.

Revision received: 8 October 2012.

Accepted for publication: 6 November 2012.

This work is licensed under a Creative Commons Attribution NonCommercial 3.0 License (CC BYNC 3.0).

(C) Copyright S.T. Odonkor and J.K. Ampofo, 2013 Licensee PAGEPress, Italy

Microbiology Research 2013; 4:e2

doi:10.4081/mr.2013.e2

changes and their impact upon human health, a significant proportion of recognized piped drinking water-related disease outbreaks are related to quality deterioration in distribution. ${ }^{17}$ Piped distribution systems for drinking water are as important to the quality and safety of drinking water as the treatment itself. Water entering the distribution system must be microbiologically safe and ideally should be biologically stable. The distribution system itself must provide a secure barrier to posttreatment contamination as the water is transported to the user. ${ }^{18}$ Potentially pathogenic bacteria from shower water and air of stem cell transport unit was isolated, ${ }^{19}$ while Enteriococcus faecalis, Clostridium perferns spore and Cryptosporidium parvum oocyst was recovered from water by using MS2 bacteriophage. ${ }^{20}$

\section{Historic perspective of indicator organisms}

Traditionally, indicator micro-organisms have been used to suggest the presence of pathogens. ${ }^{21}$ Today, however, we understand a myriad of possible reasons for indicator presence and pathogen absence or vice versa. In short, there is no direct correlation between numbers of any indicator and entire pathogens. ${ }^{22}$ To eliminate the ambiguity in the term microbial indicator, the following three groups (Table 1) are now recognized: i) general 
(process) microbial indicators, ii) faecal indicators such as $E$. coli, iii) index organisms and model organisms. A direct epidemiological approach could be used as an alternative or adjunct to the use of index micro-organisms. Yet epidemiologic methods are generally too insensitive, miss the majority of waterborne disease transmissions and are clearly not preventative. ${ }^{23}$ Nonetheless, the ideal is to validate appropriate index organisms by way of epidemiological studies. A good example is the emerging use of an enterococci guideline for recreational water quality. ${ }^{24}$ Often epidemiologic studies fail to show any relationship to microbial indicators, due to poor design and/or due to the widely fluctuating ratio of pathogen(s) to faecal indicators and the varying virulence of the pathogens. ${ }^{25,26}$

\section{Development of indicators: the coliforms}

The use of bacteria as indicators of the sanitary quality of water probably dates back to 1880 when Von Fritsch described Klebsiella pneumonia and $K$. rhinoscleromatis as microorganisms characteristically found in human faeces. ${ }^{27}$ In 1885, Percy and Grace Frankland started the first routine bacteriological examination of water in London, using Robert Koch's solid gelatin media to count bacteria. ${ }^{28}$ Also in 1885, Escherich described Bacillus coli and renamed it Escherichia coli. ${ }^{29}$

In 1891, the Franklands came up with the concept that organisms characteristic of sewage must be identified to provide evidence of potentially dangerous pollution..$^{28}$ By 1893 , the Wurtz method of enumerating $E$. coli by direct plating of water samples on litmus lactose agar was being used by sanitary bacteriologists, using the concept of acid from lactose as a diagnostic feature. This was followed by gas production, with the introduction of the Durham tube. ${ }^{30}$ The concept of coliform bacteria, those bacteria resembling $E$. coli, was in use in Britain in 1901. ${ }^{31}$ The colony count for bacteria in water, however, was not formally introduced until the first report. ${ }^{32}$

Therefore, the sanitary significance of finding various Coliforms along with streptococci and $C$. perfringens was recognized by bacteriologists by the start of the twentieth century. ${ }^{28}$ It was not until 1905, however, that MacConkay described his now famous MacConkay's broth, ${ }^{33}$ which was diagnostic for lactose-fermenting bacteria tolerant of bile salts. Nonetheless, coli-forms were still considered to be a heterogeneous group of organisms, many of which were not of faecal origin. The origins of the critical observation that $E$. coli was largely faecal in origin while other Coliforms were not, could be claimed. ${ }^{34}$

\section{Use of Escherichia coli as indicator organism}

Escherichia coli are the predominant member of the facultative anaerobic portion of the human colonic normal flora. ${ }^{35}$ The bacterium's only natural habitat is the large intestine of warm-blooded animals and since $E$. coli, with some exceptions, generally does not survive well outside of the intestinal tract, its presence in environmental samples, food, or water usually indicates recent faecal contamination or poor sanitation practices in food-processing facilities. ${ }^{36}$ The population of $E$. coli in these samples is influenced by the extent of faecal pollution, lack of hygienic practices, and storage conditions. ${ }^{35}$ The mere presence of $E$. coli in food or water does not indicate directly that pathogenic microorganisms are in the sample, but it does indicate that there is a heightened risk of the presence of other faecal-borne bacteria and viruses, many of which, such as Salmonella spp. or hepatitis A virus, are pathogenic ${ }^{37}$ For this reason, $E$. coli is widely used as an indicator organism to identify food and water samples that may contain unacceptable levels of fecal contamination. ${ }^{38}$

$E$. coli is considered a more specific indicator of fecal contamination than fecal coliforms since the more general test for fecal coliforms also detects thermotolerant non-fecal coliform bacteria. ${ }^{39}$ The $E$. coli test recommended by the United States Environmental Protection Agency (EPA) confirms presumptive fecal coliforms by testing for the lack of an enzyme which is selective for the $E$. coli organism. This test separates $E$. coli from non-fecal thermotolerant coliforms.

\section{Scientific classification of Escherichia Coli}

Kingdom: bacteria; phylum: proteobacteria; class: Gamma proteobacteria; order: Entero- bacteriales; family: Enterobacteriaceae; genus: Escherichia; species: Escherichia coli. ${ }^{36}$

Escherichia coli (commonly abbreviated $E$. coli; pronounced and named after its discoverer), is a Gram negative rod-shaped bacterium that is commonly found in the lower intestine of warm-blooded organisms (endotherms). ${ }^{40}$ Most $E$. coli strains are harmless, but some, such as serotype 0157:H7, can cause serious food poisoning in humans, and are occasionally responsible for product recalls. ${ }^{41,42}$ The harmless strains are part of the normal flora of the gut, and can benefit their hosts by producing vitamin $\mathrm{K} 2{ }^{43}$ or by preventing the establishment of pathogenic bacteria within the intestine. ${ }^{42,44}$

In fact, various classification schemes for coliforms have been emerged. The earliest were those of MacConkay, ${ }^{45}$ who recognized 128 different coliform types, while Bergey and Deehan identified $256 .{ }^{46}$ By the early 1920 s, differentiation of coliforms had come to a series of correlations that suggested indole production, gelatin liquefaction, sucrose fermentation and Voges-Proskauer reaction were among the more important tests for determining faecal contamination. ${ }^{47}$ These developments culminated in the IMViC (Indole, Methyl red, Voges-Proskauer and Citrate) tests for the differentiation of so-called faecal coliforms, soil coliforms and intermediates. ${ }^{48}$

Water sanitary engineers, however, require simple and rapid methods for the detection of faecal indicator bacteria. Hence, the simpler to identify coliform group, despite being less faecal-specific and broader (for which Escherichia, Klebsiella, Enterobacter and Citrobacter were considered the most common genera) was targeted. One of the first generally an accepted method for coliforms was called the Multiple-Tube Fermentation Test. ${ }^{49}$

New strains of $E$. coli evolve through the natural biological process of mutation, and some strains develop traits that can be harmful to a host animal. These virulent strains typically cause a bout of diarrhea that is unpleasant in healthy adults and is often lethal to children in the developing world. ${ }^{50}$ More virulent

Table 1. Definitions for indicator and index micro-organisms of public health concern. ${ }^{22}$

\begin{tabular}{ll} 
Group & Definition \\
Process indicator & $\begin{array}{l}\text { A group of organisms that demonstrates the efficacy of a process such } \\
\text { as total heterotrophic bacteria or total Coliforms for chlorine disinfection. }\end{array}$ \\
Faecal indicator & $\begin{array}{l}\text { Agroup of organisms that indicates the presence of faecal contamination } \\
\text { such as the bacterial groups thermotolerant Coliforms or E. coli. Hence, } \\
\text { they only infer that pathogens may be present. }\end{array}$ \\
\hline Index and model organisms & $\begin{array}{l}\text { Agroup/or species indicative of pathogen presence and behavior } \\
\text { respectively such as E. coli as an index for Salmonella and F-RNA } \\
\text { coliphages as models of human enteric viruses. }\end{array}$ \\
\hline
\end{tabular}


strains, such as 0157:H7 cause serious illness or death in the elderly, the very young or the immunocompromised. ${ }^{50,51}$ E. coli is Gram-negative, facultative anaerobic and non-sporulating. Cells are typically rod-shaped and are about 2 micrometres $(\mu \mathrm{m})$ long and $0.5 \mu \mathrm{m}$ in diameter, with a cell volume of $0.6-0.7 \mu \mathrm{m}^{3}{ }^{52}$ It can live on a wide variety of substrates. $E$. coli uses mixed-acid fermentation in anaerobic conditions, producing lactate, succinate, ethanol, acetate and carbon dioxide. Since many pathways in mixed-acid fermentation produce hydrogen gas, these pathways require the levels of hydrogen to be low, as is the case when $E$. coli lives together with hydrogen-consuming organisms such as methanogens or sulfate-reducing bacteria. ${ }^{53}$ 0ptimal growth of E. coli occurs at $37^{\circ} \mathrm{C}$ but some laboratory strains can multiply at temperatures of up to $49^{\circ} \mathrm{C} .{ }^{54}$ Growth can be driven by aerobic or anaerobic respiration, using a large variety of redox pairs, including the oxidation of pyruvic acid, formic acid, hydrogen and amino acids, and the reduction of substrates such as oxygen, nitrate, dimethyl sulfoxide and trimethylamine $\mathrm{N}$-oxide. ${ }^{55}$

\section{Virulence properties of $E$. Coli}

Enteric E. coli (EC) are classified on the basis of serological characteristics and virulence properties (Table 2). ${ }^{56-58}$

\section{Isolation and identification of $E$. coli}

Methods used to isolate $E$. coli as an indicator organism from food have not proved to be efficient for isolating pathogenic strains of $E$. coli. ${ }^{59}$ This is largely because pathogenic strains often differ considerably from nonpathogenic $E$. coli in growth patterns. ${ }^{60}$ Pathogenic strains frequently show delayed growth at 44 and $45.5^{\circ} \mathrm{C}$, particularly when initially present in low populations. ${ }^{54}$ Some pathogenic strains will not produce acid and gas from lactose in LST, BGLB, or EC broths within 48h. It has also been shown that growth in media containing sodium lauryl sulfate and growth at $44.5^{\circ} \mathrm{C}$ can cause a loss of plasmids, known to encode many virulence factors associated with pathogenic $E$. coli strains. ${ }^{61}$ One study indicated that up to $95 \%$ of $E$. coli cells lost plasmids during selective enrichment cultures. $^{62}$ Therefore, the methods commonly used for detection of $E$. coli as an indicator organism should not be used to attempt isolation of pathogenic strains from food or water.

Isolation of enterohemorrhagic $E$. coli 0157:H7 must be approached differently than using the methods for isolating other $E$. coli strains. ${ }^{63}$ E. coli 0157 :H7 has some biochemical differences from most of other $E$. coli strains that can be exploited in isolation and identification methods (Tables 3 and 4). E. coli 0157:H7 ferments sorbitol slowly, ${ }^{64}$ or not at all and does not produce functional $\beta$-glucuronidase, whereas most of the other $E$. coli strains are positive in both tests. Further, $E$. coli $0157: \mathrm{H} 7$ strains do not ferment rhamnose on agar plates, whereas $60 \%$ of non-sorbitolfermenting $E$. coli belonging to other serogroups ferments rhamnose on agar plates.

Several methods such as DNA probes and polymerase chain reaction (PCR), ELISA procedure utilizing monoclonal antibody (4E8C12) specific for an outer membrane protein of $E$. coli $0157: \mathrm{H} 7$ and media that can test both sorbitol fermentation and $\beta$-glucuronidase activity such as Sorbitol MacConkay agar containing MUG can be used for isolation of this organism. . $^{65} 67$

The identification and enumeration of $E$. coli of sanitary significance relies upon isolate conformance to the coliform and faecal coliform group definitions. ${ }^{68} \mathrm{E}$. coli isolates are traditionally identified by their IMViC pattern: ++- - (Type I) and - + - - (Type II). ${ }^{69}$ In this scheme I refers to the ability of the organism to produce indole from metabolism of tryptophane; $M$ indicates the ability of the organism to ferment glucose to high acid as detected by

Table 2. Virotypes of $E$. coli. ${ }^{56}$

\begin{tabular}{|c|c|c|}
\hline Name & Host & Description \\
\hline $\begin{array}{l}\text { Enterotoxigenic } \\
\text { E. coli (ETEC) }\end{array}$ & $\begin{array}{l}\text { Causative agent of diarrhea } \\
\text { (without fever) in humans, } \\
\text { pigs, sheep, goats, cattle, } \\
\text { dogs, and horses }\end{array}$ & $\begin{array}{l}\text { ETEC uses fimbrial adhesins (projections from the bacterial cell surface) to bind enterocyte cells } \\
\text { in the small intestine. ETEC can produce two proteinaceous enterotoxins: } \\
\text { - The larger of the two proteins, LT enterotoxin, is similar to cholera toxin in structure and function. } \\
\text { - The smaller protein, ST enterotoxin causes cGMP accumulation in the target cells and a subsequent } \\
\text { secretion of fluid and electrolytes into the intestinal lumen. } \\
\text { ETEC strains are non-invasive, and they do not leave the intestinal lumen. ETEC is the leading bacterial } \\
\text { cause of diarrhea in children in the developing world, as well as the most common cause of traveler's } \\
\text { diarrhea. Each year, ETEC causes more than } 200 \text { million cases of diarrhea and } 380,000 \text { deaths, mostly in } \\
\text { children in developing countries. }{ }^{57}\end{array}$ \\
\hline $\begin{array}{l}\text { Enteropathogenic } \\
\text { E. coli (EPEC) }\end{array}$ & $\begin{array}{l}\text { Causative agent of diarrhea } \\
\text { in humans, rabbits, dogs, } \\
\text { cats and horses }\end{array}$ & $\begin{array}{l}\text { Like ETEC, EPEC also causes diarrhea, but the molecular mechanisms of colonization and etiology } \\
\text { are different. EPEC lack fimbriae, ST and LT toxins, but they utilize an adhesin known as intimin to } \\
\text { bind host intestinal cells. This virotype has an array of virulence factors that are similar to those found } \\
\text { in Shigella, and may possess a shiga toxin. Adherence to the intestinal mucosa causes a rearrangement } \\
\text { of actin in the host cell, causing significant deformation. EPEC cells are moderately-invasive (i.e. they } \\
\text { enter host cells) and elicit an inflammatory response. Changes in intestinal cell ultrastructure due to } \\
\text { attachment and effacement are likely the prime cause of diarrhea in those afflicted with EPEC. }\end{array}$ \\
\hline
\end{tabular}

Enteroinvasive Found only in hum $\quad$ EIEC infection causes a syndrome that is identical to Shigellosis, with profuse diarrhea and high fever.

E. coli (EIEC)

Enterohemorrhagic Found in humans, E. coli (EHEC) cattle, and goats

The most famous member of this virotype is strain 0157:H7, which causes bloody diarrhea and no fever. EHEC can cause hemolytic-uremic syndrome and sudden kidney failure. It uses bacterial fimbriae for attachment (E. coli common pilus, ECP), 58 is moderately-invasive and possesses a phage-encoded Shiga toxin that can elicit an intense inflammatory response.

Entero Found only in humans

Enteroaggregative

E. coli (EAEC)
So named because they have fimbriae which aggregate tissue culture cells, EAEC bind to the intestinal mucosa to cause watery diarrhea without fever. EAEC are non-invasive.

They produce a hemolysin and an ST enterotoxin similar to that of ETEC. 
Methyl Red pH indicator dye in the medium; Vi stands for the production of neutral products 2.3 butanediol and/or acetoin from glucose metabolism, otherwise known as the VoguesProskauer reaction, whereas $\mathrm{C}$ represents the ability of the bacterium to use citrateas a sole carbon source. Recent data indicate that defining $E$. coli by IMViC profile is inadequate for identification of $E$. coli strains which do not give IMViC reactions corresponding to either Biotype I or Biotype II. ${ }^{69}$ The relatively high incidence of Type II $E$. coli in some specimen is at partly explained by the fact that many isolates require $48 \mathrm{~h}$ to produce a detectable amount of indole; hence, additional tests are essential for speciation.

\section{Challenges of using $E$. coli as an indicator organism}

As soon as the coliform test came into widespread acceptance, complications with its use and interpretation began to emerge. One concern was the discovery that a variety of microorganisms that read positive in the coliform test were not of fecal origin. As a result, the test method has evolved continually to become more specific. Some of the more significant developments were the so-called fecal coliform test which selects for coliforms of fecal origin by using a higher incubation temperature. ${ }^{70}$

Table 3. Biochemical properties of E. coli. ${ }^{66}$

\begin{tabular}{|c|c|c|c|c|c|}
\hline Test & E. colt & ETEC & EPEC & $E I E C$ & 0157:H7 \\
\hline Lactose fermentation & + & + & + & $\mathrm{V}$ & + \\
\hline Gas from lactose & + & + & + & - & + \\
\hline Sorbitol fermentation & + & + & + & - & $\mathrm{V}$ \\
\hline Motility & + & + & + & - & + \\
\hline Indole & + & + & + & $\mathrm{V}$ & + \\
\hline Methyl red & + & + & + & + & + \\
\hline Voges-Proskauer & - & - & - & - & - \\
\hline Citrate & - & - & - & - & - \\
\hline Lysine decarboxylation & + & + & + & $\mathrm{V}$ & + \\
\hline Ornithine decarboxylation & V & $\mathrm{V}$ & $\mathrm{V}$ & - & + \\
\hline$\beta$-Glucuronidase & + & + & + & + & - \\
\hline
\end{tabular}

ETEC, enterotoxigenic E. coli; EPEC, enteropathogenic E. coli; EIEC, enteroinvasive $E$. coli;,$+>90 \%$ positive; -, <10\% positive; v, 10-90\% positive.

Table 4. Biochemical tests used for identification of Escherichia coli. ${ }^{67}$

\begin{tabular}{lcc} 
Biochemical test properties & $\begin{array}{c}\text { Escherichia coli } \\
\text { reaction }\end{array}$ & $\begin{array}{c}\% \text { of isolates with same } \\
\text { reaction as } \boldsymbol{E}_{\text {. coli }}\end{array}$ \\
Gram staining & G-, small rod, pink & 99 \\
EMB & BCMS & 99 \\
\hline Citrate test & - & 80 \\
Oxidase test & - & 75 \\
\hline Indole test & + & 75 \\
Methyle red test & + & 75 \\
\hline Voges-Proskauer test & - & 60 \\
Sugar fermentation & + & 90 \\
\hline Catalase test & + & 65 \\
Lactose test & + & 90 \\
\hline Urea hydrolysis test & + & 75 \\
Nitrate reduction test & + & 80 \\
Gelatin hydrolysis test & + & 75 \\
Casein hydrolysis test & + & 65 \\
\hline G-, gram negative; BCMS, black centered colony with metallic sheen;+, 90-100\% of the isolates were positive; -, 0-10\% of the isolates were
\end{tabular}

Though, disease-causing strains of $E$. coli species have been isolated from tap water, drinking water sources and mountain streams,${ }^{71}$ examination of pathogenic $E$. coli is not easy due to the uncertainty in determining the pathogenic nature of isolated $E$. coli strains. There is no biochemical marker that can separate pathogenic from non-pathogenic strains and the relationship between serotype and pathogenicity is questionable. ${ }^{71}$

The use of $E$. coli as an indicator organism is somewhat restricted by the fact that $E$. coli is not a single species; ${ }^{72}$ certain genera of the coliform group such as Proteus and Aerobacter are normally found outside the human intestinal tract in soil; other organisms found in water that do not represent fecal pollution possess some of the characteristics attributed to $E$. coli and E. coli identical to that found in humans is also found in the intestinal tract of other warm-blooded animals. ${ }^{73}$ However, primarily, studies have shown that $E$. coli is a much better indicator of disease risk than is faecal coliform, ${ }^{74}$ EPA has therefore, recommended that $E$. coli be used as a criteria for classifying waters for fresh water contact recreation. Another weakness of the faecal coliform test and perhaps any indicator organism test geared to human waste is that there are some bacterial pathogens which are unrelated to human wastes. ${ }^{72}$ To the degree that naturally occurring microbial pathogens become a significant public health concern, completely new test procedures may have to be developed.

Furthermore, while $E$. coli is specific for faecal contamination, there are three inherent problems of using $E$. coli as a confirmation of faecal contamination: ${ }^{75} \mathrm{i}$ ) it is outnumbered by other types of fecal bacteria making it more difficult to find; ii) it does not survive for long outside of the gut; iii) it can be found in pristine environments in the tropics. Therefore, the absence or presence of $E$. coli via a culture test does not absolutely confirm the absence or presence of faecal contamination. The $E$. coli tests used today as an indication of fecal contamination are commonly culture tests although there are PCR tests for the pathogenic strain E.coli 0157:H7 and for enterotoxigenic strains. ${ }^{76}$

In addition to the inherent differences in the ecology of the above mentioned indicator organism, there is also the problem using culturable tests. ${ }^{75}$ All culture tests have an inherent bias in that they always underestimate the number of $E$. coli present in the sample. This occurrence happens for a number of reasons, but in the instance of recovering faecal indicators, the bias is primarily for two reasons: i) some healthy coliforms are viable but will not grow in the media prescribed for them; and ii) coliforms found in the environment are often stressed thereby making recovery very difficult despite the growth media used. 


\section{Current trends of $E$. coli as indicator organism}

While the faecal coliform test has its limitations and problems, it also has many attributes. Perhaps, the most significant attribute is that: as a regulatory tool, it has worked long and well. ${ }^{77}$ In the case of water quality regulation, coliform testing has been used successfully for well over fifty years. For the foreseeable future, the faecal coliform test will continue to be the basis for much of the regulatory decision making regarding both quality water harvesting and contact recreation. ${ }^{78}$ The primary bias of using culturable tests in isolating E. coli as an indicator organism, has being overcome by using PCR, which detects both live and dead bacteria. ${ }^{76}$

The PCR is a rapid and reliable tool for the molecular-based diagnosis of a variety of infectious diseases. ${ }^{76}$ PCR analysis for screening drinking water and environmental samples has been reported, ${ }^{76,79}$ and has been utilized to identify $E$. coli in primary water specimens, stool specimens and outbreaks. ${ }^{80}$

\section{Conclusions}

In conclusion its clear that $E$. coli appears to be the best indicator of bacteriological quality of water, primarily because of the, availability of affordable, fast, sensitive, specific and easier to perform detection methods for $E$. coli. However the fact remains that the life span of $E$. coli in water is short, thus it best determines, recent contaminations. It is therefore important that there is continuous monitoring for $E$. coli to determine the bacteriological quality of water.

\section{References}

1. Ashbolt NJ, Grabow WO, Snozzi M. Indicators of microbial water quality. In: Fewtrell F, Bartram J, eds. Water quality guidelines, standards and health assessment of risk and risk management for water-related infectious disease. Geneva: World Health Organization; 2001. pp. 256276.

2. Gadgil A. Drinking water in developing countries. Annu Rev Energy Environ 1998; 23:253-86.

3. Gerald P. Water science. University of Washington. Available from: http://faculty.washington.edu/ghp/researcthemes/wa ter-science. Accessed on: February 2011.

4. Dooge JCI. Integrated management of water resources. In: Ehlers E, Krafft T, eds. Understanding the earth system: compartments, processes, and interactions. Berlin: Springer; 2001. p 116.

5. Comprehensive Assessment of Water Management in Agriculture. Water for food, water for life: a comprehensive assessment of water management in agriculture. London: Earthscan, and Colombo: International Water Management Institute; 2007.

6. Burton GA, Gunnison D, Lanza JR. Survival of pathogenic bacteria in various freshwater sediments. Appl Environ Microbiol 1987;53:633-8.

7. Gelover S, Gomez LA, Reyes K, Leal MT. A practical demonstration of water disinfection using TiO2 films and sunlight. Water Res 2006;40:3274-80.

8. The supply side constraints of Ghana's water sector. Available from: Allafrica.com/stories/200611281208. Accessed: January 2013.

9. Addo KK, Mensah G, Bekoe M, et al. Backeriological quality of sachet water produced and sold in Teshi-Nungua suburbs of Accra, Ghana. Volume 9. Available from: www.ajfand.net/Volume9/No4/Addo 9125.pdf

10. Payment P. Epidemiology of endemic gastrointestinal and respiratory diseasesincidence, fraction attributable to tap water and cost to society. Water Sci Technol 1997; 35:7-10.

11. Dufour A, Snozzi M, Koster W, et al. Assessing microbial safety of drinking water, improving approaches and methods. Available from: http://www.who.int/ water_sanitation_health/dwq/924154630 1/en/

12. Issac-Renton J, Moorhead W, Ross A. Longitudinal studies of Giardia contamination in two adjacent community drinking water supplies: cyst levels, parasite viability and health impact. Appl Environ Microbiol 1996;62:47-54.

13. Hunter PR. Waterborne diseases epidemiology and ecology. Chichester: Wiley; 1997.

14. Pruss A, Kay D, Fewtrell L, Bartram J. Estimating the burden of disease due to water, sanitation and hygiene at global level. Environ Health Perspect 2002;110:537-42.

15. Craun GF. Water quality in Latin America balancing the microbial and chemical risks in drinking water disinfection. Washington DC; Life Science Inst; 1996. p 211.

16. Le-Chavallier MW, Au KK. Water treatment for pathogens control process efficiency in achieving safe drinking water. WHO 2004. Available from: a p p s.w h o. in t/i ri s/bi t - stream/.../9241562552.pdf

17. Cheryl D, Mark W, Le-Chavallier MW. A pilot study of bacteriological population changes through potable water treatment and distribution. Appl Environ Microbiol 2000;66:268-76.

18. Geldreich EE, Le-Chavellier MW. Microbiological quality control in distribution systems. In: Letterman RD, ed. Water supplies. 5th ed. New York: McGraw-Hill; 1999. pp 1-49.

19. Perkins SD, Mayfield J, Fraser V, Angenent LT. Potentially pathogenic bacteria in shower water and air of stem cell transport unit. Appl Environ Microbiol 2009;75:5363-72.

20. Smith CM, Hill VR. Dead-end hollowfibre-ultrafiltration for revovery of diverse microbes from water. Appl Environ Microbiol 2009;75:5284-9.

21. Berg G. The indicator system. In: Berg G, ed. Indictors of viruses in water and food. Ann Arbor: Ann Arbor Science Pub; 1978. pp 1-13.

22. Grabow WOK, Neubrech TE, Holtzhausen CS, Jofre J. Bacteroides fragilis and Escherichia coli bacteriophages: excretion by humans and animals. Wat Sci Technol 1995;31:223-30.

23. Frost FJ, Craun GF, Calderon RL. Waterborne disease surveillance. J AWWA 1996;88:66-75.

24. WHO. Guidelines for safe recreationalwater environments. Vol. 1. In: Coastal and fresh-waters. (Draft for consultation. WHO/EOS/98.14.) Geneva: World Health Organization; 1998.

25. Fleisher JM. The effects of measurement error on previously reported mathematical relationships between indicator organism density and swimming-associated illness: a quantitative estimate of the resulting bias. Int $\mathbf{J}$ Epidemiol 1990;19;1100-6.

26. Fleisher JM. A re-analysis of data supporting US federal bacteriological water quality criteria governing marine recreational waters. Res J Wat Pollut Contr Fed 1991;63:259-65.

27. Geldreich EE. Bacterial populations and indicator concepts in feces, sewage, stormwater and solid wastes. In: Berg G, ed. Indicators of viruses in water and food. Ann Arbor: Ann Arbor Science Pub. 1978. pp 51-97.

28. Hutchinson M, Ridgway JW. Microbiological aspects of drinking water supplies. London: Academic Press; 1977. p 180.

29. Escherich T. Die Darmbakterien des Neugeborenen und Säuglings. Fortschr J Med 1885;3:515-54.

30. Durham HE. A simple method for demonstrating the production of gas by bacteria. 
Brit J Med 1898;1:1387.

31. Horrocks WH. An introduction to the bacteriological examination of water. London: Churchill; 1901.

32. HMSO. The microbiology of water 1994: Part 1-Drinking water. Reports on Public Health and Medical Subjects. No. 71. In: Methods for the examination of water and associated materials. London: HMSO; 1994.

33. MacConkey AT. Lactose-fermenting bacteria in faeces. J Hyg 1905;5:333.

34. Winslow CEA, Hunnewell MP. Streptococci characteristic of sewage and sewage-polluted waters. J Sci 1902;15:827.

35. Krieg NR, Holt JG, eds. Bergey's manual of systematic bacteriology. Baltimore: Williams; 1984. pp 408-20.

36. Feng P, Weagant S, Grant M. Enumeration of Escherichia coli and the coliform bacteria. In: FDA/Center for Food Safety \& Applied Nutrition, 8th ed. Bacteriological analytical manual. 8th ed. Available from: http://www.cfsan.fda.gov/ ebam/bam4.html.

37. Brüssow H, Canchaya C, Hardt WD. Phages and the evolution of bacterial pathogens: from genomic rearrangements to lysogenic conversion. Microbiol Mol Biol Rev 2004;68:560-602.

38. Atlas J, Ronald M, Richard B. Microbial ecology: fundamentals and applications. Redwood City: Cummings; 1993. pp 633 688.

39. Francy DS, Donna N, Myers T, et al. Escherichia coli and fecal coliform bacteria as indicators of recreational water quality. Water Resources Investigations Report 93-4083. Available from: http://pubs.usgs.gov/wri/1993/4083/report. pdf. Accessed on: January 2013

40. George M, Garrity R, eds. The gammaproteobacteria. Bergey's manual of systematic bacteriology. 2nd edition. New York: Williams; 2005. p. 1108.

41. Hudault S, Guignot J, Servin AL. Escherichia coli strains colonizing the gastrointestinal tract protect germ-free mice against Salmonella typhimurium infection. Gut 2001;49:47-55.

42. Vogt RL, Dippold L. Escherichia coli 0157:H7 outbreak associated with consumption of ground beef, June-July 2002. Public Health Rep 2005;120:174-8.

43. Bentley R, Meganathan R. Biosynthesis of vitamin $\mathrm{K}$ (menaquinone) in bacteria. Microbiol Rev 1982;46:241-80.

44. Reid G, Howard J, Gan BS. Can bacterial interference prevent infection? Trends Microbiol 2001;9:424-8.

45. MacConkey AT. Further observations on the differentiation of lactose-fermenting bacilli with special reference to those of intestinal origin. J Hyg 1909;9:86.

46. Bergey DH, Deehan SJ. The colon-aerogenes group of bacteria. J Med Res 1908;19:175.

47. Hendricks CW. Exceptions to the coliform and the fecal coliform tests. In: Berg G, ed. Indicators of viruses in water and food. Ann Arbor: Ann Arbor Sci; 1978. pp 99-145.

48. Parr LW. The occurrence and succession of coliform organisms in human feces. Am J Hyg 1938;27:67.

49. Fung DYC, Cox NA, Bailey JS. Rapid methods and automation in the microbiological examination of food. Dairy Food Sanit 1988;8:292-6.

50. Nataro JP, Kaper JB. Diarrheagenic Escherichia coli. Clin Microbiol Rev 1998;11:142-201.

51. Blankenhorn D, Phillips J, Slonczewski JL. Acid- and base-induced proteins during aerobic and anaerobic growth of Escherichia coli revealed by two-dimensional gel electrophoresis. J Bacteriol 1999;181:2209-16.

52. Kubitschek HE. Cell volume increase in Escherichia coli after shifts to richer media. J Bacteriol 1990;172:94-101.

53. Madigan MT, Martinko JM. Brock biology of microorganisms. 11th ed. San Francisco: Pearson Education Inc.; 2006. p 13.

54. Fotadar U, Zaveloff P, Terracio L. Growth of Escherichia coli at elevated temperatures. J Basic Microbiol 2005;45:403-4.

55. Ingledew WJ, Poole RK. The respiratory chains of Escherichia coli. Microbiol Rev 1984;48:222-71.

56. Todar K. Pathogenic E. coli. Available $\begin{array}{lllll}\mathrm{f} & \mathrm{r} & 0 & \mathrm{~m}\end{array}$ http://textbookofbacteriology.net/e.coli_2. html.

57. Evans Jr, Doyle J, Dolores GE. Escherichia Coli. Medical Microbiology, 4th edition. The University of Texas Medical Branch at Galveston. Available from: http://web.archive.org/web/200711020628 13/http://www.gsbs.utmb.edu/microbook/c h025.htm

58. Rendón MA, Saldaña Z, Erdem AL, et al. Commensal and pathogenic Escherichia coli use a common pilus adherence factor for epithelial cell colonization. Proc Natl Acad Sci USA 2007;104:10637-42.

59. Barrett T, Feng P, Swaminathan, B. Amplification methods for detection of foodborne pathogens. In: Lee $\mathrm{HH}$, Morse SA, Olsvik 0, eds. Nucleic acid amplification techniques: application to disease diagnosis. Cambridge; Eaton Publishing; 1997. pp 171-181.

60. Griffin PM, Tauxe RV. The epidemiology of infections caused by Escherichia coli 0 157:H7, other enterohemorrhagic E. coli, and the associated hemolytic uremic syndrome. Epidemiol Rev 1991;13:60-98.

61. March SB, Ratnam S. SorbitolMacConkey medium for detection of Escherichia coli 0157:H7 associated with hemorrhagic colitis. J Clin Microbiol 1986;23:869-72.

62. March SB, Ratnam S. Latex agglutination test for detection of Escherichia coli serotype 0157:H7. J Clin Microbiol 1989; 27:1675-7.

63. Borczyk AA, Harnett N, Lombos M, Lior H. False-positive identification of Escherichia coli 0157:H7 by commercial latex agglutination tests. Lancet 1990;336: 946-7.

64. Geldreich EE, Le-Chavellier M. Microbiological quality control in distribution systems. In: Letterman RD, ed. Water supplies, 5th ed. New York: McGraw-Hill; 1999. pp 18-49.

65. Entis P. Hydrophobic grid membrane filter/MUG method for total coliform and Escherichia coli enumeration in foods: collaborative study. J Assoc Off Anal Chem 1989;72:936-50.

66. Meng J, Doyle MP, Zhao T, Zhao S. Escherichia coli 0157:H7. In: Doyle MP, Beauchat LR, Montville TJ, eds. Food microbiology: fundamentals and frontiers, 2nd ed. Washington DC: ASM Pess; 2001. pp 193-213.

67. Min J, Baeumner D. Highly sensitive and specific detection of viable Escherichia coli in drinking water. J Anal Bioch 2001; 303:186-93.

68. Leclercq A, Wanegue C, Baylac P. Comparison of fecal coliform agar and violet red bile lactose agar for fecal coliform enumeration in foods, Appl Environ Microbiol 2002;68:1631-8.

69. Paton JC, Paton AW. Pathogenesis and diagnosis of Shiga toxin-producing Escherichia coli infections. Clin Microbiol Rev 1998;11:450-79.

70. Geldreich EE. Sanitary significance of fecal coliforms in the environment. (Water pollution control research series). Washington DC: U.S. Dept. of the Interior, Federal Water Pollution Control Administration; 1966.

71. Cleseri LS. Standard methods for the examination of water and wastewater. Washington: American Public Health Association; 1998.

72. Eckner KF. Comparison of membrane filtration and multiple-tube fermentation by the Colilert and Enterolert methods for detection of waterborne coliform bacteria, Escherchia coli and enterococci used in drinking and bathing water quality monitoring in Southern Sweden. Appl Environ Microbiol 1998;64:3079-83.

73. Hoffmann H, Sturenburg E, Heesemann 
J, Roggenkamp A. Prevalence of extended-spectrum $\beta$-lactamases in isolates of the Enterobacter cloacae complex from German hospitals. Clin Microbiol Infect 2006;12:322-30.

74. EPA. Report of task force on guide standard and protocol for testing microbiological water purifiers. Washington DC: United States Environmental Protection Agency; 1986. pp 1-29.

75. USEPA. Improved enumeration methods for the recreational water quality indicators: Enterococci and Escherichia coli. Washington DC: Office of Science and Technology; 2000.
76. Hartman PA, Swaminathan B, Curiale SM, et al. Rapid methods and automation. In: Vanderzant C, Splittstoesser DF, eds. Compendium of methods for the microbiological examination of foods. 3rd ed. Washington DC: American Public Health Association; 1992. pp 39665-39746.

77. Feng PCS, Hartman PA. Fluorogenic assays for immediate confirmation of Escherichia coli. Appl Environ Microbiol 1982;43:1320-29.

78. Frampton EW, Restaino L. Methods for E. coli identification in food, water and clinical samples based on beta-glucuronidase detection. J Appl Bacteriol 1993;74:223-
33.

79. Feldsine PT, Falbo-Nelson MT, Hustead DL. Colicomplete substrate-supporting disc method for confirmed detection of total coliforms and Escherichia coli in all foods: comparative study. J AOAC Int 1993; 76:988-1005.

80. Gevaert K, Van Damme J, Goethals M, et al. Chromatographic isolation of methionine-containing peptides for gel-free proteome analysis: identification of more than 800 Escherichia coli proteins. Mol Cell Proteomics 2002;1:896-903. 